\title{
The Existence of FGFR1-5-HT1A Receptor Heterocomplexes in Midbrain 5-HT Neurons of the Rat: Relevance for Neuroplasticity
}

\begin{abstract}
Dasiel O. Borroto-Escuela, ${ }^{1}$ Wilber Romero-Fernandez, ${ }^{1}$ Mileidys Pérez-Alea, ${ }^{2}$ Manuel Narvaez, ${ }^{3}$ Alexander 0. Tarakanov, ${ }^{4}$ Giuseppa Mudó, ${ }^{5}$ Luigi F. Agnati, ${ }^{6}$ Francisco Ciruela, ${ }^{7}$ Natale Belluardo, ${ }^{5}$ and Kjell Fuxe ${ }^{1}$ ${ }^{1}$ Department of Neuroscience, Karolinska Institutet, SE-171 77 Stockholm, Sweden, ${ }^{2}$ School of Life and Health, Aston University, Birmingham B4 7ET, United Kingdom, ${ }^{3}$ Department of Physiology, School of Medicine, University of Málaga, 29071 Málaga, Spain, ${ }^{4}$ St. Petersburg Institute for Informatics and Automation, Russian Academy of Sciences, 199178 Saint Petersburg, Russia, ${ }^{5}$ Department of Experimental Picine and Clinical Neurosciences, Laboratory of Molecular Neurobiology, University of Palermo, IT-90134 Palermo, Italy, ${ }^{6}$ Istituto Di Rice ro e Cura Carattere Scientifico, 30126 Lido Venice, Italy, and 7 Unitat de Farmacologia, Departament Patologia i Terapèutica Experimental, Unir Asita re Barce ona, 08907 Barcelona, Spain

The ascending midbrain 5-HT neurons to the forebrain may be dysregulated epressic have a reduced trophic support. With in situ proximity ligation assay (PLA) and supported by coimmunoprecipitation and location of the FGFR1 and 5-HT1A immunoreactivities in the midbrain raphe cells, evidence for the existence of FGFR1-5 ATIA receptor heterocomplexes in the dorsal and median raphe nuclei of the Sprague Dawley rat as well as in the rat medullary raphe R 33B cells has been obtained. Especially after combined FGF-2 and 8-OH-DPAT treatment, a marked and significant increase in PLAcluster was and in the RN33B cells. Similar results were reached with the FRET technique in HEK293T cells, where TM-V of the 5HT1 rec or was found to be part of the receptor interface. The combined treatment with FGF-2 and the 5-HT1A agonist also syner-icall creased FGFR1 and ERK1/2 phosphorylation in the raphe midline area of the midbrain and the RN33B cells as well as the diffe entia on, as seen from development of the increased number and length of extensions per cell and their increased 5-HT impun se ctivity. These signaling and differentiation events were dependent on the receptor interface since they were blocked by $\mathrm{j}$ bation ith TM-V but not by TM-II. Together, the results indicate that the 5-HT1A autoreceptors by being part of a FGFR1-5-HT IA rea tor heterocomplex in the midbrain raphe 5-HT nerve cells appear to have a trophic role in the central 5-HT neuron systems $i$ addition to aying a key role in reducing the firing of these neurons.
\end{abstract}

\section{Introduction}

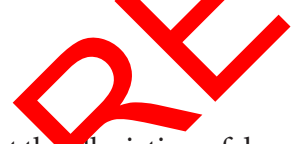

Compelling evidence shows that the reviation of depression caused by serotonin-selective reuptake inhib, rs (SSRIs) is produced by increasing the availability of serotonin at the postjunctional 5-HT receptor subtypes in combination with a downregulation of the 5-HT1A autoreceptors in the raphe regions (Albert et al., 1996; Artigas et al., 1996). A dysregulation of the 5-HT1A autoreceptors leading to a marked reduction of the firing rate in the ascending raphe-forebrain 5-HT neurons has been implicated in major depression (Albert et al., 2011). It seems possible that a certain balance of activity at different postjunctional 5-HT receptor subtypes of the

Received Aug. 15, 2011; revised Feb. 24, 2012; accepted March 1, 2012.

Author contributions: D.O.B.-E., L.A., F.C., N.B., and K.G.F. designed research; D.0.B.-E., W.R.-F., M.P.-A., M.N., A.O.T., G.M., F.C., N.B., and K.G.F. performed research; N.B. and K.G.F. contributed unpublished reagents/analytic tools; D.O.B.-E., W.R.-F., M.P.-A., M.N., A.O.T., G.M., L.A., F.C., N.B., and K.G.F. analyzed data; D.O.B.-E. and K.G.F. wrote the paper.

This work has been supported by the Torsten and Ragnar Söderberg Foundation (MN 65/08), Telethon TV3's La Marató Foundation 2008 and M.M. Wallenberg Foundation to K.G.F., and Karolinska Institutets Forskningsstiftelser 2010 and 2011 to D.0.B-E. It was also supported by Grants SAF2008-01462 and Consolider-Ingenio CSD2008-00005 from Ministerio de Ciencia e Innovación to F.C. A.O.T. has not received any support for this work.

Correspondence should be addressed to Professor Kjell Fuxe, Retzius väg 8, 17177 Stockholm, Sweden. E-mail: Kjell.Fuxe@ki.se.

DOI:10.1523/JNEUROSCI.4203-11.2012

Copyright $\odot 2012$ the authors $\quad 0270-6474 / 12 / 326295-09 \$ 15.00 / 0$ seven 5-HT receptor families identified (Hoyer et al., 2002) needs to be developed with time through adaptive changes to counteract the depression (Fuxe et al., 1991). In fact, certain antidepressant drugs may as part of their action block certain 5-HT2-like receptors (Fuxe et al., 1977; Ogren et al., 1979; Peroutka and Snyder, 1979, 1980).

Antidepressant drugs and chronic electroconvulsive shock treatment increase the expression of FGF-2 in frontal cortices and hippocampus (Follesa et al., 1994; Gwinn et al., 2002; Mallei et al., 2002; Maragnoli et al., 2004), suggesting a beneficial role of FGF-2 in mood disorders. It is therefore of interest that FGFR1 is constitutively expressed in neurons of target brain regions involved in depression, including the raphe 5-HT nuclei (Belluardo et al., 1997). FGF-2, a trophic factor binding to FGFR1, is widely expressed in the brain both in astrocytes and neurons (Fuxe et al., 1996) and is coexpressed in the perikarya of practically all raphe 5-HT nerve cells (Chadi et al., 1993; Fuxe et al., 1996).

The above findings open up the possibility that antidepressant drugs, by increasing extracellular 5-HT levels, leading to an enhancement of the 5-HT1A autoreceptor signaling in the raphe nuclei, can cause an activation of the FGF-2/FGFR1 mechanism in the raphe 5-HT nerve cells. In line with this hypothesis, extended treatment with the SSRI zimelidine causes increases in 5-HT immunofluorescence in the dorsal raphe (Fuxe et al., 
1983). The receptors for epidermal growth factor, plateletderived growth factor, insulin-like growth factor-1, FGFs, and neurotrophins can, in fact, be transactivated in response to GPCR activation even in the absence of neurotrophic factor binding at the cell surface via direct (heteromeric receptor complexes) and/or indirect GPCR/RTK receptor interactions (Luttrell et al., 1999; Lee and Chao, 2001; Kotecha et al., 2002; Lee et al., 2002; Ferguson, 2003; Rajagopal et al., 2004; Shah and Catt, 2004; Berghuis et al., 2005; Fuxe et al., 2007). Evidence is here presented for the existence of FGFR1-5-HT1A receptor heterocomplexes in the mesencephalic raphe 5-HT nerve cells. Upon coactivation of the receptor protomers they produce a substantial enhancement of plasticity in stable cell lines of medullary raphe 5-HT nerve cells. We therefore propose a new role of the 5-HT autoreceptors in the central 5-HT nerve cell bodies, namely one of neurotrophism through transactivation of FGFR1 in the discovered receptor heterocomplex as observed both in in vivo and in vitro experiments.

\section{Materials and Methods}

Chemicals, reagents, and drug administration. ( S)-N-tert-Butyl-3-(4-(2methoxyphenyl)-piperazin-1-yl)-2-phenylpropanamide dihydrochloride ((S)-WAY 100135 dihydrochloride), 2-[(1,2-dihydro-2-oxo-3H-indol 3-ylidene)methyl]-4-methyl-1 $H$-pyrrole-3-propanoic acid (SU 5402), $\mathrm{N}$-[2-[[4-(diethylamino)butyl]amino]-6-(3,5-dimethoxyphenyl)pyrido [2,3-d]pyrimidin-7-yl]-N'-(1,1-dimethylethyl)urea (PD173074), and ( \pm )7-hydroxy-2-dipropylaminotetralin hydrobromide (8-OH-DPAT hydrobromide) were purchased from Tocris Bioscience. FGF-2 was purchased from Cell Signaling Technology. DMEM, penicillin/streptomycin, and fetal bovine serum were purchased from Invitrogen. Restriction zymes were from New England Biolabs, and coelenterazine 400 was obtain from MRW. The injected amounts (intracerebroventricularly) wer ug 8-OH-DPAT and 50 ng of FGF-2 unless otherwise indicated. P osph FGF Receptor 1 (Tyr653/654) (55H2) mouse monoclonal an chased from Cell Signaling Technology. Rabbit polyclon 5-HT1A receptor (ab44635), mouse monoclonal [M 1 . FFFR1 3829) antibodies were obtained from Abcam. Rabbit $p$ onoclona nnti-5-HT1A (vtg544) antibody was obtained from VTG Big cences, Monoc.nnal mouse anti-phospho-ERK1/2 and rabbit monoclon ant o-HT antibodies were from Sigma-Aldrich. Mouse anti-NeuN mono onal cibody was purchased from Millipore. Secondary infr ed p be-la crabbit-anti-mouse antibodies were from LI-COR Biosc ces alyor 488-conjugated goat anti-mouse IgG and the Alexa Fluor s -conjugated goat anti-rabbit IgG were from Invitrogen.

Plasmid constructs. The cDNA encoding the human 5-HT1A and FGFR1 without its stop codon was subcloned in $\mathrm{pGFP}^{2}-\mathrm{N} 1$ (PerkinElmer) and pEYFP-N1 (Clontech) using standard molecular biology and PCR techniques.

Cell culture, transfection, and RNA interference. HEK293T or RN33B cells (a CNS-derived neuronal precursor cell line; Lundberg et al., 2002; American Type Culture Collection) were grown in DMEM/F12 supplemented with $2 \mathrm{~mm}$ L-glutamine, $100 \mathrm{U} / \mathrm{ml}$ penicillin/streptomycin, and $10 \%(\mathrm{v} / \mathrm{v})$ fetal bovine serum at $37^{\circ} \mathrm{C}$ and in an atmosphere of $5 \% \mathrm{CO}_{2}$. For transfection, cells were plated in 6-well dishes at a concentration of $1 \times 10^{6}$ cells/well or in $75 \mathrm{~cm}^{2}$ flasks and cultured overnight before transfection. Cells were transiently transfected (cDNA molar ratio 1:1) using linear PolyEthylenImine reagent (PEI) (Polysciences Inc.). siRNAs against rat FGFR1 and 5-HT1A (Dharmacon) were from Thermo Scientific. Nonsilencing siRNA Alexa Fluor 488 was from Qiagen (catalog $\# 1022563$ ) and used as a negative control. Cells were plated the day before transfection in 12-well culture dishes coated with poly-D-lysine (BD BioCoat) and then transfected with the corresponding SMARTpool siRNA kit (Dharmacon, Thermo Scientific).

Transmembrane peptide treatment. A series of peptides, representing each of the predicted TM segments for the human 5-HT1A (UniProt identifier number P08908), were synthesized by VTG Biosciences by using 9-fluorenylmethoxycarbonyl chemistry and purified by means of
HPLC analysis (reverse phase C4 column) to $\geq 98 \%$ purity. TM-I peptide consisted of residues 37-62 (VITSLLLGTLIFCAVLGNACVVAAIA); TM-II peptide of residues 74-98 (LIGSLAVTDLMVSVLVLPMAALYQ V); TM-III peptide of residues 110-132 (DLFIALDVLCCTSSILHLCAIA L); TM-IV peptide of residues 153-178 (AAALISLTWLIGFLISIPPMLG WRTP); TM-V peptide of residues 192-217 (DHGYTIYSTFGAFYIPLLL MLVLYGR); TM-VI peptide of residues 346-367 (TLGIIMGTFILCWL PFFIVALV); and TM-VII peptide of residues 379-403 (TLLGAIINWL GYSNSLLNPVIYAYF). At the C-terminal juxtamembrane sequence of each TM peptide was introduced the tribasic sequence (RKR) as found in many membrane proteins to reduce possible artifact formation through disulfide bridges and to ensure incorporation into the plasma membrane of cells, as has been demonstrated previously (Bennasroune et al., 2004, 2005). Immediately before use, the peptides were solubilized in dimethyl sulfoxide (DMSO) and diluted in the corresponding cell culture medium to yield a final concentration of $1 \%$ DMSO. We verified that, for each tested concentration of DMSO alone, no effect on cell viability was observed. Cells were incubated with the above mentioned peptides at $37^{\circ} \mathrm{C}$ for $2 \mathrm{~h}$ before performing FRET analysis or signaling assays. Incorporation of the peptide into cellular membranes under these conditions was checked with a rhodami

Double immunolab ng histo emistry. Adult aged-matched male mice were anesthet ed a perfu d intracardially with $4 \%(\mathrm{w} / \mathrm{v})$ paraformaldehyde/P orains $\mathrm{P}$. emoved, postfixed by immersion overnight in $4 \%$ pa forr aldehyde/PBS, and coronal sections $(20 \mu \mathrm{m})$ were cut on a y atom and $\mathrm{p}$ cessed for free-floating immunohistochemistry. Se were p abilized with buffer A containing $0.2 \%$ Triton $\mathrm{X}-100$ for $5 \mathrm{~m}$, and then preincubated in a blocking buffer containing $0 \%(\mathrm{w} / \mathrm{v})$ Tritu and $4 \%(\mathrm{w} / \mathrm{v})$ bovine serum albumin. After $1 \mathrm{~h}$ at bom tem erature, sections were labeled with the indicated primary anodies ff $1 \mathrm{~h}$, extensively washed, and stained with the indicated fluo nce-labeled secondary antibodies. Samples were rinsed and vilized on a Leica SP2 confocal microscope. The primary antibodies used were as follows: rabbit polyclonal antiserum against 5-HT1A receptor (ab44635) (5 $\mu \mathrm{g} / \mathrm{ml}$; Abcam) and mouse monoclonal [M2F12] (ab829) antibodies against FGFR1 ( $5 \mu \mathrm{g} / \mathrm{ml}$;Abcam). The secondary antibodies used were as follows: Alexa Fluor 488-conjugated goat antimouse IgG (1:2000; Invitrogen), and Alexa Fluor 546-conjugated goat anti-rabbit IgG (1:2000; Invitrogen).

Proximity ligation in situ assay (Duolink). In situ proximity ligation assay (PLA) was performed as described previously (Söderberg et al., 2006; Borroto-Escuela et al., 2010, 2011; Trifilieff et al., 2011). Freefloating sections and RN33B cell cultures were used with the following primary antibodies: rabbit monoclonal anti-5HT1A (VTG Biosciences) and mouse monoclonal anti-FGFR1 (Abcam). Control experiments used only one primary antibody or cells transfected with cDNAs encoding only one type of receptor. PLA signal was visualized and quantified by using a confocal microscope Leica TCS-SL confocal microscope (Leica) and the Duolink Image Tool software.

Coimmunoprecipitation experiments. For immunoprecipitation, HEK293T cell membranes from transiently transfected cells or raphe membranes obtained from the caudal midline area of the midbrain tegmentum, containing the dorsal raphe and medianus raphe, were solubilized in ice-cold RIPA buffer (comprising, in mm: 50 Tris-HCl, pH 7.4, $100 \mathrm{NaCl}, 1 \%$ Triton X-100, $0.5 \%$ sodium deoxycholate, $0.2 \%$ SDS, and 1 EDTA) for $30 \mathrm{~min}$ on ice. The solubilized preparation was then centrifuged at $10,000 \times g$ for $30 \mathrm{~min}$. The supernatant $(1 \mathrm{mg} / \mathrm{ml})$ was processed for immunoprecipitation, each step of which was conducted with constant rotation at $0-4^{\circ} \mathrm{C}$. The supernatant was incubated overnight with the indicated antibody. Then $50 \mu \mathrm{l}$ of a suspension of TrueBlot antimouse Ig IP beads (eBioscience) was added and the mixture was incubated overnight. Subsequently, the beads were washed twice with ice-cold RIPA buffer, twice with ice-cold RIPA buffer diluted 1:10 in TBS (50 mM Tris- $\mathrm{HCl}, \mathrm{pH} 7.4,100 \mathrm{~mm} \mathrm{NaCl}$ ), and once with TBS, and aspirated to dryness with a 28 -gauge needle. Then, $100 \mu \mathrm{l}$ of SDS-PAGE sample buffer (0.125 м Tris-HCl, pH 6.8, 4\% SDS, 20\% glycerol, 0.004\% bromphenol blue) was added to each sample. Immune complexes were dissociated by adding fresh DTT (50 mu final concentration) and heating to $100^{\circ} \mathrm{C}$ for 10 min. Proteins were resolved by SDS/PAGE performed in $10 \%$ polyacryl- 
amide gels. Proteins were transferred to PVDF membranes using a semidry transfer system and immunoblotted with the indicated antibody and then with HRP-conjugated goat anti-rabbit IgG or HRP-conjugated anti-mouse IgG TrueBlot ULTRA (eBioscience). The immunoreactive bands were developed using a chemiluminescent detection kit (Pierce). We are aware that we have not used midbrain sections from 5-HT1A-null mutant mice as negative controls. However, this additional control will be made in further experiments, although the 5-HT1A-FGFR1 coimmunoprecipitation data in the midbrain could be validated in cellular models.

FRET experiments. Forty-eight hours after transfection, HEK293T cells with constant $(1 \mu \mathrm{g})$ or increasing amounts of cDNA of FGFR $1{ }^{\text {GFP2 }}$ and 5-HT1A ${ }^{\text {YFP }}$ or 5-HT2A ${ }^{\text {YFP }}$, respectively, were rapidly washed twice in PBS, detached, and resuspended in the same buffer. Cell suspensions (40 $\mu \mathrm{g}$ of total protein) were distributed in duplicates into 96 -well microplates, and $\mathrm{GFP}^{2}$ and YFP fluorescence were measured with a POLARstar Optima plate reader (BMG Labtech), using excitation filters at $410 \mathrm{~nm}$ (10 $\mathrm{nm}$ bandwidth) and $485 \mathrm{~nm}$ (12 nm bandwidth), as well as emission filters corresponding to $510 \mathrm{~nm}$ (10 $\mathrm{nm}$ bandwidth), and 530 $\mathrm{nm}$ (10 $\mathrm{nm}$ bandwidth), respectively. Mock-transfected cells were used for background subtraction. FRET signals were collected using 410/10 $\mathrm{nm}$ excitation and 530/10 nm emission filters. Removal of acceptor bleedthrough and correction of acceptor fluorescence intensity changes were performed as previously described (Borroto-Escuela et al., 2010, 2011).

In cell Western phosphorylation assay. Nondifferentiated and in some cases differentiated RN33B cells were treated at the indicated concentration and times of each 5-HT1A and FGFR1 agonist or antagonist and then fixed in a final concentration of $4 \%$ paraformaldehyde. After fixing, the cells were permeabilized by washing 5 times $(0.1 \%$ Triton X-100 in PBS), blocked for $90 \mathrm{~min}$ at room temperature in LI-COR Odyssey Blocking Buffer, and then incubated overnight at $4^{\circ} \mathrm{C}$ with primary monoclonal mouse anti-phospho-ERK1/2 antibody (Sigma-Aldrich, diluted 1:10,000) or primary monoclonal mouse anti-phospho-FGFR1 tibody (Cell Signaling Technology, diluted 1:1000). Then, after extensi wash, cells were incubated in the dark with secondary infrare waro labeled rabbit-anti-mouse antibodies (diluted 1:1500) an tion stains (DRAQ5, Sapphire700) for $1 \mathrm{~h}$ at room tempera and scanned by the Odyssey infrared scanner (LI-CO

$R N 33 B$ cell differentiation. Sterile poly-D-lysineused to grow RN33B cells at a density of 2 Agonists were added to nondifferentiated ce during 48 h fter which the medium was changed and the same rand were added to fresh nonsupplemented medium and incubation cont al for $48 \mathrm{~h}$ at $37^{\circ} \mathrm{C}$. Cells were then fixed with $4 \%$ cold arato adehyde $(\mathrm{w} / \mathrm{v})$, the coverslips were mounted on slides, nnd 11 were analyzed. Brightfield images were obtained using an mpus IX70 with a Q-Fire CCD camera. Average number of extensions, or 1000 cells was determined and the mean extension lengths from measurement of 100 cells were quantified per condition in three independent experiments; length was converted into micrometers and analyzed for statistical significance.

Studies on RN33B cell differentiated before agonist treatment. At a confluence of $80 \%$, cells were transferred to complete serum-free B16 medium ( $0.5 \%$ BSA, Sigma Aldrich) and were differentiated by shifting the temperature from $33^{\circ} \mathrm{C}$ ( $2 \mathrm{~d}$ incubation) to $39^{\circ} \mathrm{C}(2 \mathrm{~d})$ and $5 \% \mathrm{CO}_{2}$ in room air.

5-HT immunocytochemistry. RN33B cells were treated under different pharmacological conditions as indicated and grown for an additional $48-56 \mathrm{~h}$ (in the case of TM peptide incubation, neurons were incubated $2 \mathrm{~h}$ before pharmacological treatment). RN33B cells were stained with rabbit anti-5-HT monoclonal antibody ( $5 \mu \mathrm{g} / \mathrm{ml}$; Sigma-Aldrich) and mouse anti-NeuN monoclonal antibody ( $5 \mu \mathrm{g} / \mathrm{ml}$; Millipore). The secondary antibodies used were as follows: Alexa Fluor 488-conjugated goat anti-mouse IgG (1:2000; Invitrogen), Alexa Fluor 546-conjugated goat anti-rabbit IgG (1:2000; Invitrogen). Each image was acquired with a Leica SP2 confocal microscope $(40 \times)$ and consisted of one image as a single $z$-scan image. Acquisition of microscopy images and 5-HT immunoreactivity semiquantifications was performed by investigators blind to the experimental condition. 5-HT immunoreactivity semiquantification is expressed as 5-HT immunoreactivity field area/number of NeuNpositive cells. Typically, images of 200-300 cells per condition were captured for each experiment and four independent experiments were performed. The application settings were adjusted at the beginning of analysis and kept the same for all images in the experiment.

Animals and drugs. Male Sprague Dawley rats, 8 weeks old, weighing 310-350 g and obtained from Charles River Laboratories, were used for all experiments. The animals were housed under a $12 \mathrm{~h}$ light/dark cycle under constant environmental conditions, with ambient temperature of $21 \pm 2^{\circ} \mathrm{C}$, relative humidity of $40-50 \%$, and with food and water available ad libitum. The number of rats in each treated group was three and the total number of rats used in this study was 36 . All efforts were made to minimize the number of animals used and their suffering. All experimental procedures were performed in accordance with the European Communities Council Directive (86/609/EEC).

Surgical preparation. Rats were anesthetized with sodium pentobarbital (40 mg/kg, i.p., Nembutal injection, Dainippon Pharmaceutical) and placed in a stereotaxic frame. Body temperature was maintained at $37^{\circ} \mathrm{C}$ and a cannula for intracerebroventricular injection of samples was implanted into the right lateral ventricle according to coordinates obtained from the work of Paxinos and Watson (1986) [anterior-posterior (AP) coordinates referred to bregma, lateral (L) coordinates to the midsagittal suture line, and ventral (V)aordinates to the surface of the skull; AP, $-1.4 \mathrm{~mm} ; \mathrm{L}, \pm 2.2 \mathrm{~mm}$. nd V, $4.3 \mathrm{~mm}$ (injection site)]. A permanent guide cannula was ma tained in lace by dental cement anchored by stainless screws fiy do th kull nd fitted with an obturator. Five days after surgery, ty obtu itors e removed and a 28 -gauge injector cannula was in re cendin $1.5 \mathrm{~mm}$ below the tip of the guides. The microini fon can la as connected via PE-20 tubing to a Hamilton syring mo ted on a syringe pump (Harvard Apparatus). Rats were mi jected th recombinant human FGF-2 (50 ng), 8-OH-DPAT $0.2 \mu \mathrm{M})$, combined treatment with TM-II synthetic peptide $(0.4 \mu \mathrm{M})$, ombined reatment with TM-V synthetic peptide $(0.4 \mu \mathrm{M})$, combined th tmen or artificial CSF (aCSF) for a control group. Fresh solutions were prepared immediately before the injections by dissolving the peptian agonists in aCSF (composition of the aCSF solution, in mM: 120 $\mathrm{NaCl}, 20 \mathrm{NaH}_{2} \mathrm{CO}_{3}, 2 \mathrm{KCl}, 0.5 \mathrm{KH}_{2} \mathrm{PO}_{4}, 1.2 \mathrm{CaCl}_{2}, 1.8 \mathrm{MgCl}_{2}, 0.5$ $\mathrm{Na}_{2} \mathrm{SO}_{4}$, and $6.8 \mathrm{D}$-glucose). Total volumes were infused (FGF-2, $2 \mu \mathrm{l}$; 8-OH-DPAT, $3 \mu \mathrm{l}$; TM synthetic peptides, $3 \mu \mathrm{l}$ ) in freely moving animals at $2.0 \mu \mathrm{l} / \mathrm{min}$, and injection cannula was left in place for another minute to prevent backflow of the solution. The animals were killed 6, 12, or $24 \mathrm{~h}$ after the infusions.

Data analysis. The number of samples $(n)$ in each experimental condition is indicated in figure legends. All data were analyzed using the commercial program Prism 4.0 (GraphPad). When two experimental conditions were compared, statistical analysis was performed using an unpaired $t$ test. Otherwise, statistical analysis was performed by one-way ANOVA followed by Tukey's Multiple Comparison post hoc test. The $P$ value 0.05 and lower was considered significant. FRET isotherms were fitted using a nonlinear regression equation assuming a single binding site.

\section{Results}

\section{FGFR1-5-HT1A receptor heterocomplexes in the dorsal and median raphe nuclei, in RN33B and HEK293T cells}

We used three different approaches: in situ PLA, coimmunoprecipitation, and the FRET technology, supplemented with double immunohistochemistry.

\section{Midbrain raphe region}

In situ PLA

PLA-positive red clusters were found in large number of nerve cells of the dorsal and median raphe nuclei, but were absent elsewhere in the surrounding areas e.g., in the deep gray layer of the superior colliculus and the central periaqueductal gray, dorsomedial region (Fig. 1A). The specificity was demonstrated by the fact that no PLA clusters were observed in HEK293T cells singly transfected with FGFR1 or with the 5-HT1A receptors (Fig. 1B). 

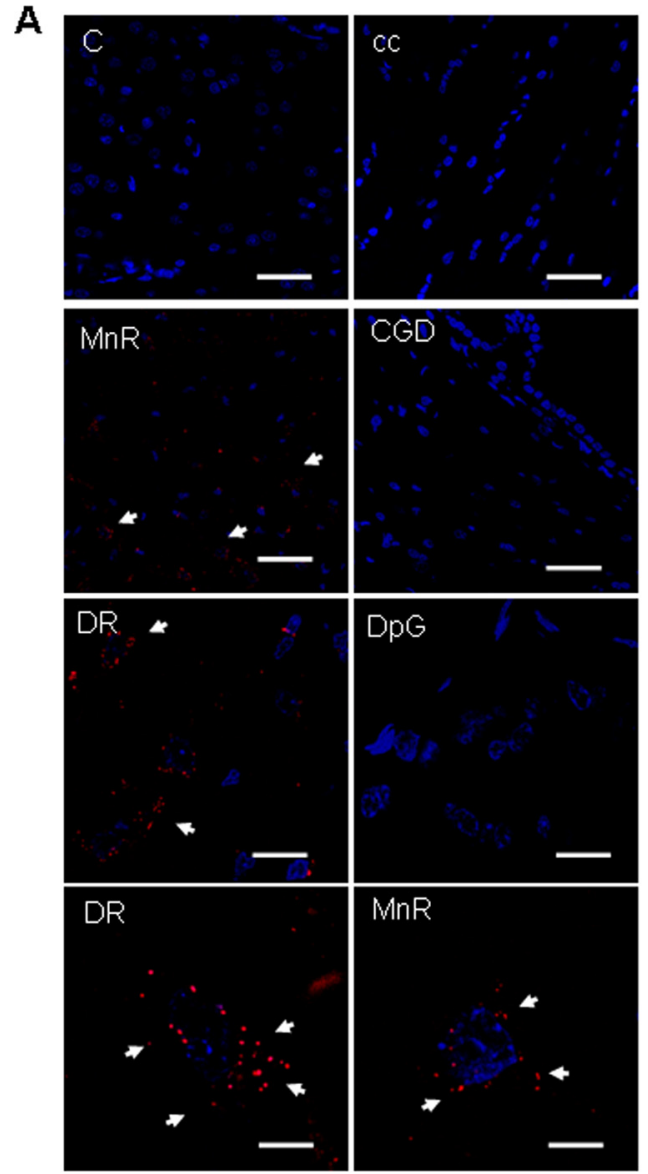

B

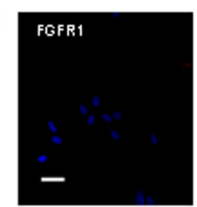

D

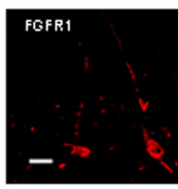

E
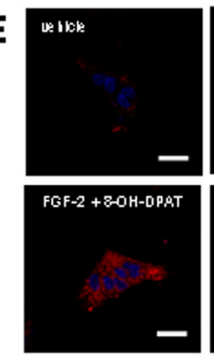

$\mathbf{F}$

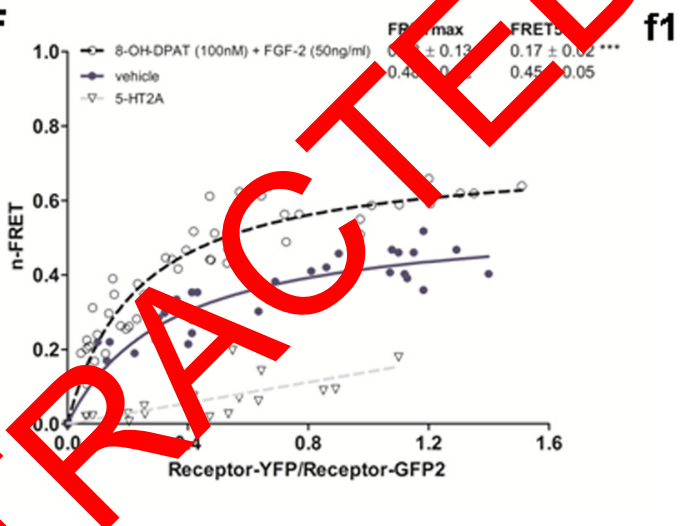

C
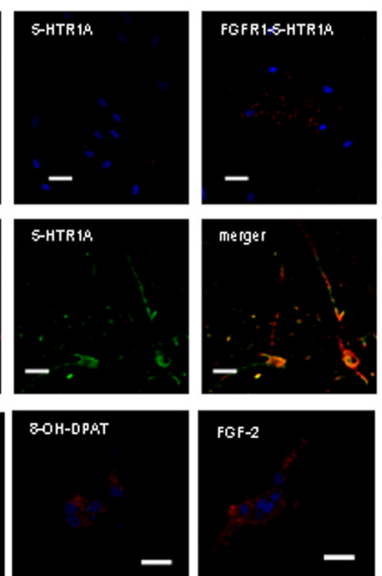

FGF-2

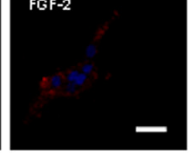

e1
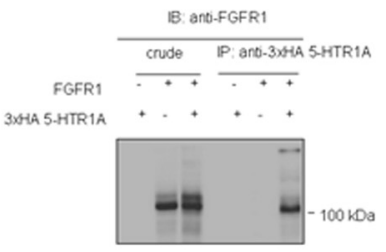

B. ant. HA

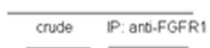

FGFR1

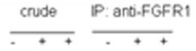

3XHA 5.HTR1A
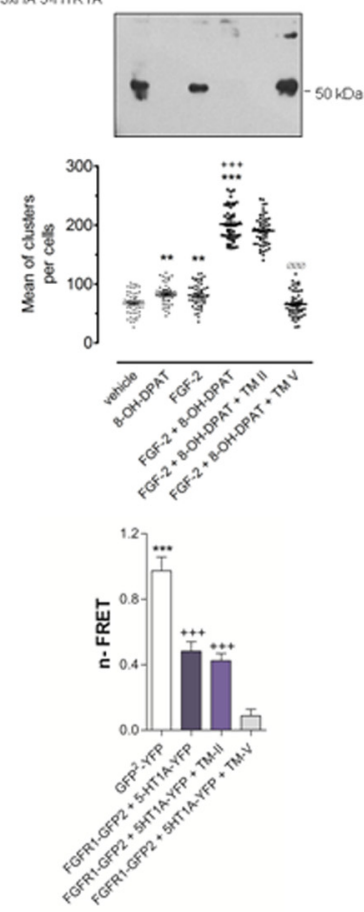

Figure 1. FGFR1 and 5-HT1A receptor heterocomplexes and reir agonist reg trion. A, Detection of neuronal cytoplasmatic FGFR1-5-HT1A receptor heterocomplexes (seen as red clusters indicated by arrows) in dorsal and median raphenucleiby insitu PLA; nucle seshow mblue (DAPI). Scale bars: fourtop panels, $10 \mu \mathrm{m}$; fourbottom panels, $50 \mu \mathrm{m}$. C, Cortex; cc, corpuscallosum;MnR, median raphenucleus; DR, dorsal raphe nucleus; $C G D$, central gray dorsal part; DpG, a o layer of he superior colliculus. B, Specific in situ PLA controls were performed in HEK293T cells. HEK293T cells were transiently transfected

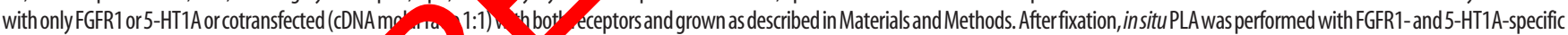
antibodies, followed by PLA reagents. The deted a recept heteroco wplexes are represented by the fluorescent PLA puncta (red clusters). Each punctum represents a high concentration of fluorescence from the single-molecule amplification resulting from ave ar nunturewold replication of the DNA circle formed as a result of the probe proximity. Nuclei are shown in blue (DAPI). Scale bars, $10 \mu \mathrm{m}$. C, Specific coimmunoprecipitation of FGFR1 and 5-HT1A in HEK 2 T cells. HEK293T cells were transfected with FGFR1 alone, 5-HT1A receptor alone, or combined FGFR1-5-HT1A cDNA. The solubilized lysates were incubated with anti-HA (top) or anti-FGFR1 (bottom) to immunoprecipitate the 3XHA-5-HT1A or FGFR1 receptors, respectively, and the resultant immunoprecipitates were examined with Western blot for anti-FGFR1 (top) or anti-HA (bottom) immunoreactivity. As shown in the right lanes of both panels, specific coimmunoprecipitation of FGFR1 and 3xHA-5HT1A was observed. The positions of molecular mass standards are indicated on the right side of each panel. D, FGFR1 (in red) and 5-HT1A (in green) immunoreactivities are observed in the same section and shown to colocalize in dorsal and median raphe nerve cells as seen from the yellow-orange color that developed (merger). Scale bars, $10 \mu \mathrm{m}$. E, Increased FGFR1-5-HT1A receptor heterocomplex formation upon receptor coactivation in rat raphe RN33B cells. Cells were treated with vehicle (-), 8-OH-DPAT (100 nM), FGF-2 (50 ng/ml), or combined 8-OH-DPAT + FGF-2 (100 nм and $50 \mathrm{ng} / \mathrm{ml}$, respectively) and each TM peptide $(0.4 \mu \mathrm{m})$ for $24 \mathrm{~h}$, and samples were processed for detection of in situ PLA signals. Scale bar, $75 \mu \mathrm{m}$. $\mathbf{e 1}$, Quantification of receptor complexes as red clusters/DAPI-positive nuclei was made in 25 cells per plate and performed on four plates. Thus each point in the scatter plot represent one cell and all the cells ( 100 cells) from the four different experiments are included. The lines in each group represent the mean value. Statistical analysis was performed $(n=4)$ by one-way ANOVA followed by Tukey's Multiple Comparison post hoc test. 8-OH-DPAT (100 nM) and FGF-2 $(50 \mathrm{ng} / \mathrm{ml})$ groups are significantly different compared with vehicle $\left({ }^{* *} p<0.01\right)$, combined 8-0H-DPAT + FGF-2 group is significantly different compared with 8-OH-DPAT $(100 \mathrm{~nm})$ and FGF-2 $(50 \mathrm{ng} / \mathrm{ml})$ alone group $\left({ }^{+++} p<0.001\right)$ or vehicle $\left({ }^{* * *} p<0.001\right) .8-0 \mathrm{H}-\mathrm{DPAT}+\mathrm{FGF}-2+\mathrm{TM}-\mathrm{V}$ group is significantly different

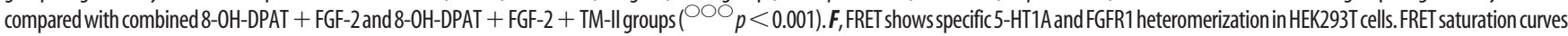
were generated in HEK293T cells expressing a fixed amount ofFGFR1-GFP2 and increasing amounts of 5-HT1A-YFP or 5HT2A-YFP. Cells were preincubated 10 min with vehicle or with 8-0H-DPAT and FGF-2 (100

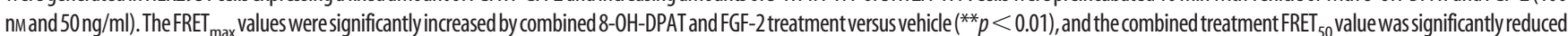
versus vehicle $(* * * 00.001)$. The 5-HT1A/FGFR1 curve fitted better to a saturation curve than to a linear regression as found with 5HT2A/FGFR1 (Ftest, $p<0.001)$. Data are means \pm SEM $(n=5)$. $f 1$, The effect of different 5-HT1A receptor TM synthetic peptides on FRET signals of the 5-HT1A-FGFR1 receptor heterocomplexes. Values represent the maximal saturable normalized FRET values. Means \pm SEM; $n=4,6$ replicates. Statistical analysis was performed by one-way ANOVA followed by Tukey's Multiple Comparison posthoctest. The FGFR1-GFP2 + 5HT1A-YFP and FGFR1-GFP2 + 5HT1A-YFP with TM peptide ll groups as well as the chimera group (GFP2-YFP) are significantly different from the FGFR1-GFP2 +5 HT1A-YFP with TM peptide V group alone $\left({ }^{+++} p<0.001\right.$ and ${ }^{* * *} p<0.001$, respectively). The concentration of the synthetic TM peptides used is $0.4 \mu \mathrm{m}$ in all experiments.

\section{Coimmunoprecipitation}

Coimmunoprecipitation was performed on extracts of the caudal midline midbrain area containing the dorsal and median raphe nuclei (see Notes). The bottom panel in the supplemental material displays the immunoblot obtained with anti-5HT1A antibodies re- vealing the presence and position of the 5-HT1A-immunoreactive bands after immunoprecipitation of the FGFR1 receptors. Furthermore, coimmunoprecipitation experiments were performed in transiently transfected HEK293T cells coexpressing FGFR1 and 3xHA5HT1A receptors (Fig. 1C), corroborating the results on brain. 
In line with these results, extensive colocalization of FGFR1 and 5-HT1A immunoreactivities was observed in the nerve cells of the dorsal raphe and the median raphe (Fig. $1 D$ ).

Raphe RN33B cells: In situ PLA

The existence of FGFR1-5-HT1A receptor complexes was also demonstrated with PLA in raphe RN33B cells. The mean number of PLA red clusters per cell was found to be significantly increased by FGF-2 or 8-OH-DPAT treatment alone, and this increase was significantly enhanced upon combined treatment (Fig. 1E,e1).

\section{HEK293T cells: FRET technique}

A saturation FRET curve was obtained in HEK293T cells coexpressing a constant amount of the FGFR1-GFP2 plasmid while increasing the amount of the 5-HT1A-YFP plasmid but not with the 5-HT2AYFP plasmid. Cotransfection of FGFR1 and 5-HT2A led only to a linear regression and thus these receptors failed to specifically interact (Fig. 1F). Treatment of 5HT1A-FGFR1-cotransfected cells with FGF-2 and 8-OH-DPAT significantly reduced the FRET $_{50}$ values and increased the FRET $_{\max }$ signal (Fig. $1 F$ ). Thus, the combined treatment substantially increases the recruitment of the receptor heterocomplex and increases the affinity of the interaction between the two protomers. In preliminary FRET experiments we observed that the most important TM interface interaction between the FGFR15-HT1A receptor corresponds to the TM-V and potentially also TM-VII. Incubations with TM-IV and TM-VI failed to block the FRET signal (see Notes). FRET competition experiments with synthetic peptides of TM-II and TM-V of the 5-HT1A receptor were performed (Fig. 1f1). TM-V incubation resulted in a significant loss of the 5HT1A capacity to interact with FGFR1, where TM-II totally ineffective.

\section{FGFR1 transactivation, ERK1/2 phosphorylation} differentiation of RN33B cells

The 5-HT1A agonist modulation of the FGFR1 go, st-respo se in RN33B cells is displayed in Figure $2 A$. Both ${ }^{2}$ 5-HT1 and FGFR1 agonists produced a rise of FGFR1 phosp orylat on with combined treatment resulting in a synergistic actio ne 8- $\mathrm{OH}-\mathrm{DPAT}$ enhancement of FGFR1 transactiy ar is up racted by both 5-HT1A (S-WAY-10013) and F FR1 D1730/4) antagonists.

The consequences of the 5-Hi -induced increase in pFGFR1 on its signaling were studied by ana sis of single and combined FGF-2 and 8-OH-DPAT treatment on ERK1/2 phosphorylation (Fig. $2 B$ ). The synergistic increase of pERK1/2 by combined FGF-2 and 5-HT1A agonist treatment was blocked by FGFR1 inhibitors and by the 5-HT1A antagonist and in siRNAfgfr1- or siRNA5htlatransfected cells. Nonsilencing siRNA control did not block this increase in the pERK1/2 (Fig. $2 B$ ). Proper controls for the silencing effect of each siRNA were done on induction of CREB and SRE promoters (see Notes). Similar results on pERK1/2 by combined FGF-2 and 5-HT1A agonist treatment were obtained in cells that had been differentiated before agonist treatment by means of an elevation of temperature to $39^{\circ} \mathrm{C}$ for $48 \mathrm{~h}$ (see Notes).

The time course experiments of ERK1/2 phosphorylation are shown in Figure 2C. Combined treatment with the 5-HT1A and FGFR1 agonists produced a synergistic increase of ERK1/2 phosphorylation starting already after $5 \mathrm{~min}$ and was still maintained after $120 \mathrm{~min}$.

It is of substantial interest that the receptor interface of the FGFR1-5-HT1A receptor complex appeared to be crucial for this synergism since it was counteracted by incubation with TM-V of the 5-HT1A receptor but not with TM-II (Fig. $2 A, C$ ). Thus, the 5-HT1A agonist-induced synergistic activation of both FGFR1 transactivation and ERK1/2 phosphorylation appears to be dependent on the receptor interface of the FGFR1-5-HT1A receptor heterocomplex.

To obtain a morphological correlate to the synergistic increase of pERK1/2 seen with FGF-2 and the 5-HT1A agonist cotreatment, effects of this combined treatment have been studied on RN33B cell differentiation (number and length of neurites, and degree of 5-HT immunoreactivity). In Figure $2 \mathrm{D}$ it is demonstrated that this combined treatment produced a highly significant increase in the number of extensions per 1000 RN33B cells after a 24-48 h incubation. The neuritic extensions were much longer and the cell somata more elongated (Fig. 2D). This increase was blocked not only by FGFR1 inhibitors and by the 5-HT1A antagonist (data not shown) but also by TM-V, while TM-II was ineffective.

Potential effects of 5HT1A-FGFR1 receptor heterocomplex on the serotonergic properties of RN33B cells showed that in the absence of agonist treatment, very few RN33B cells were 5-HT positive (Fig. 2E). Sem thative image analysis showed that FGF-2 incubation $c$ ased an ncrease in the number of 5-HTimmunoreactive $\mathrm{N}_{3}$, cells with high fluorescence intensity. Robust increa s in 5- H nunoreactivity were only seen with combined tre at. RN33B cells cultured in the presence of 8-OH-D AT alo e d not increase 5-HT immunoreactivity above, on levels. n addition, no significant differences in the number of h h-5-HT IR-expressing cells were detected from at seen with FGF-2 alone when cells were incubated in the resence f synthetic peptide TM-V.

GFR1 transactivation and ERK1/2 phosphorylation in the caudal midline area of the midbrain after in vivo treatment with FGF-2 and/or 8-OH-DPAT given

\section{intracerebroventricularly}

In vivo results have been obtained by exploring the effects of intracerebroventricular treatment with $8-\mathrm{OH}-\mathrm{DPAT}(200 \mathrm{nmol})$ and/or FGF-2 (50 ng) on pFGFR1 and pERK1/2 levels in the rat caudal midline area of the midbrain containing the dorsal and median raphe nuclei (Fig. $3 A, B$ ). Upon combined intracerebroventricular treatment with $8-\mathrm{OH}-\mathrm{DPAT}$ and FGF-2, a synergistic and significant increase of phosphorylation of FGFR1 and ERK1/2 was observed at 6,12 , and $24 \mathrm{~h}$ in the caudal midline area of the midbrain. As seen in Figure 3, $a 1$ and $b 1$, prior intracerebroventricular treatment $(1 \mathrm{~h})$ with TM-V but not with TM-II markedly counteracted the synergistic increase of the FGFR1 and ERK1/2 phosphorylation found after combined treatment with the FGF-2 and 8-OH-DPAT as seen in the 6-24 h time interval studied.

\section{Discussion}

We show for the first time the existence of FGFR1-5-HT1A receptor heterocomplexes in 5-HT nerve cells of the dorsal and median raphe nuclei of the midbrain by means of the PLA technique as has previously been postulated (Fuxe et al., 2007). These 5-HT neurons are known from previous work to express FGFR1 and to contain high amounts of 5-HT1A immunoreactivity and a high density of 5-HT1A binding sites (Pazos and Palacios, 1985; Albert et al., 1996; Artigas et al., 1996; Belluardo et al., 1997).The PLA-positive clusters have a location in the cytoplasm and are also associated with the plasma membrane. They were in addition demonstrated with the PLA technique in stable cell lines from the medullary raphe neurons, all showing observable 5-HT IR in their cytoplasm in agreement with previous work (Czesak et al., 2007). The specificity of the in situ PLA was indicated from the 

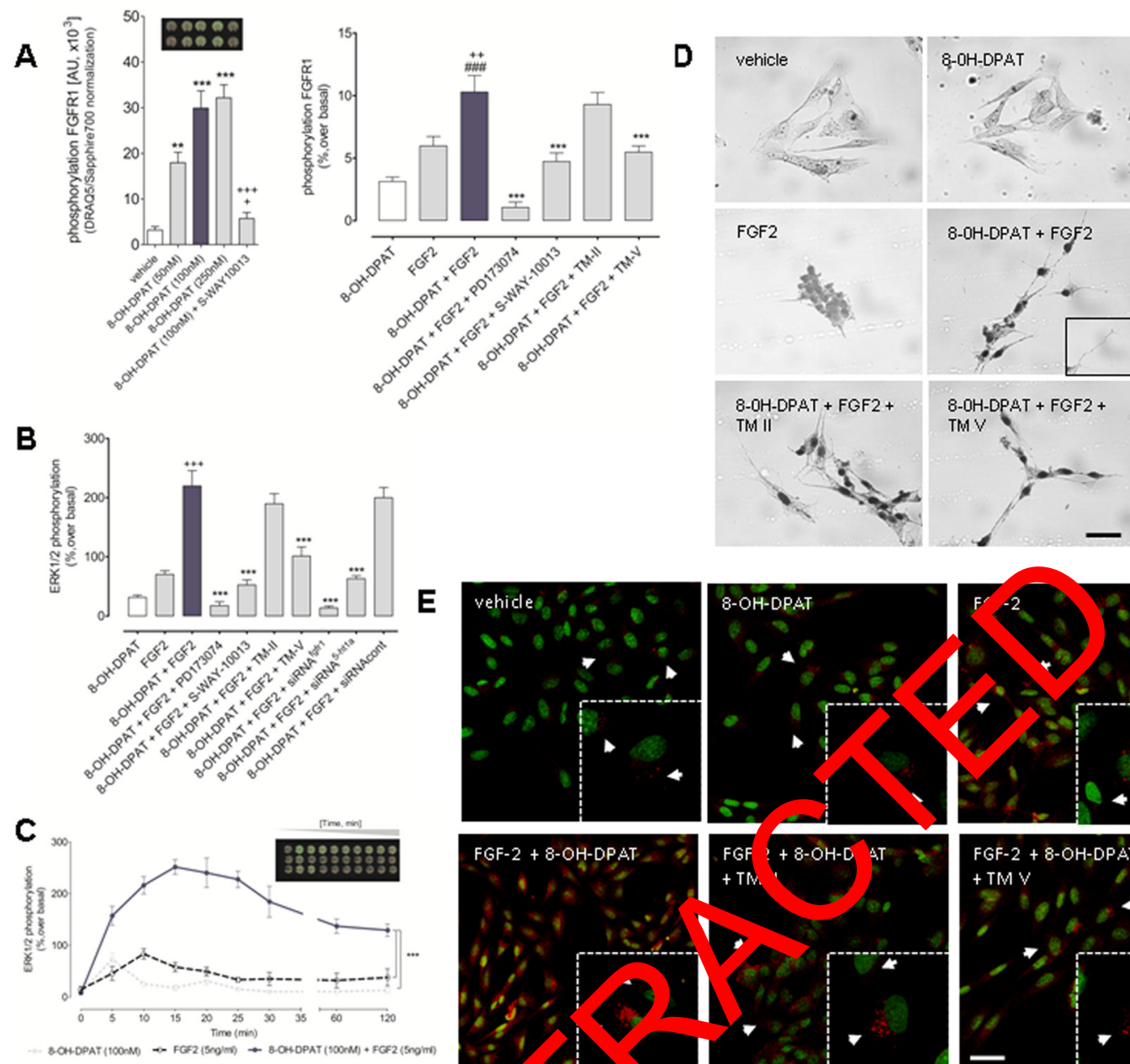

d1

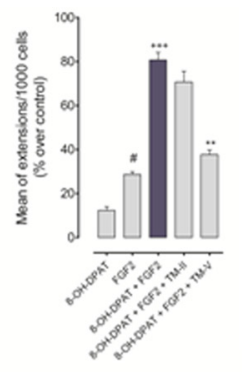

d2
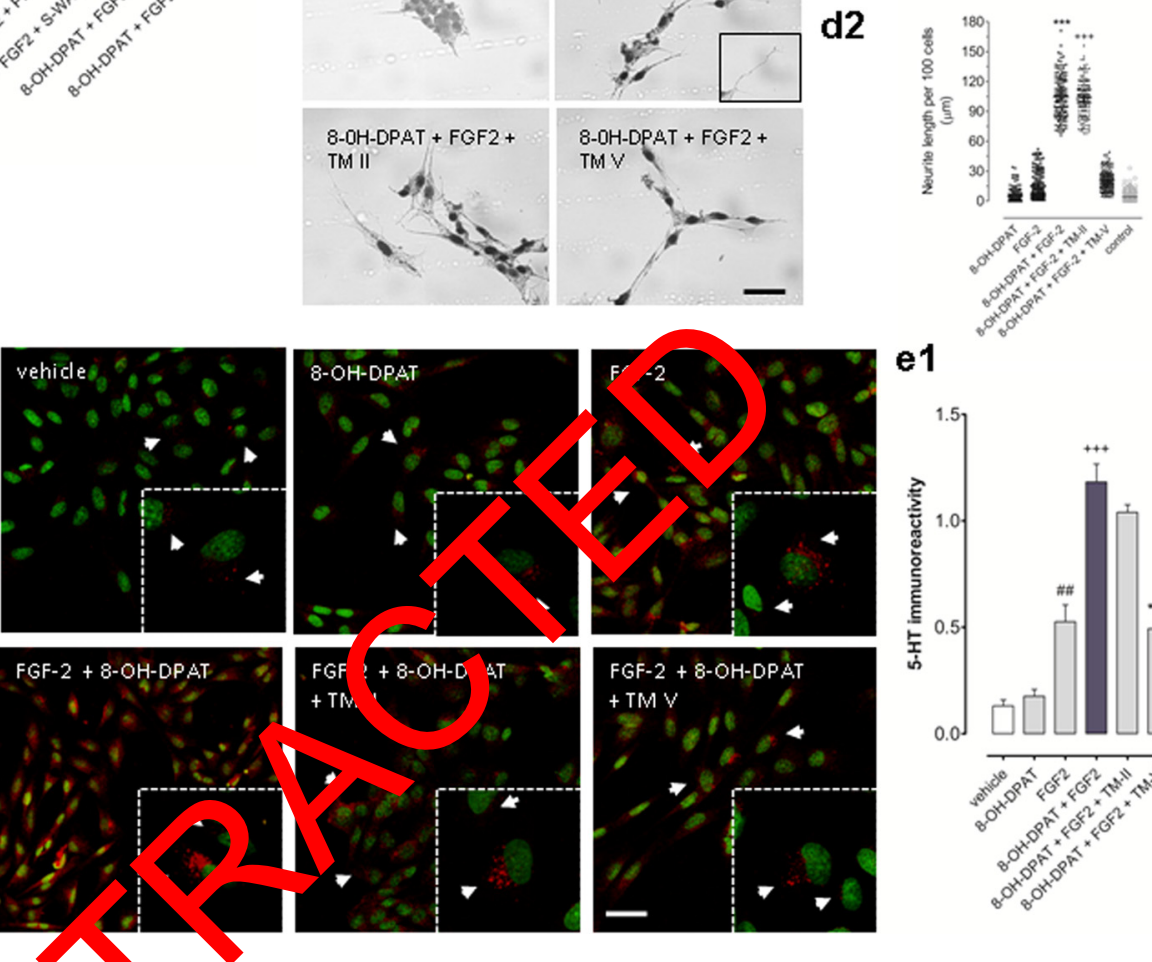

e1

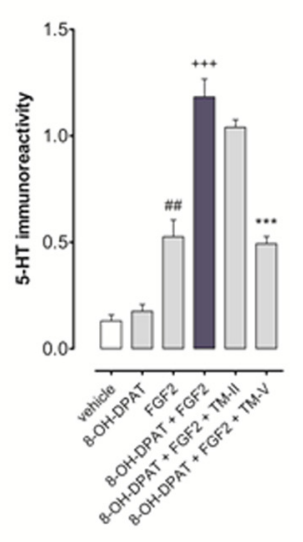

Figure 2. FGFR1-5-HT1A receptor-receptor interactions iny ing FGFR1 th sactivation, ERK1/2 phosphorylation, and structural plasticity in RN33B cells. $\boldsymbol{A}$, $\boldsymbol{B}$, Synergistic activation of the FGFR1 and

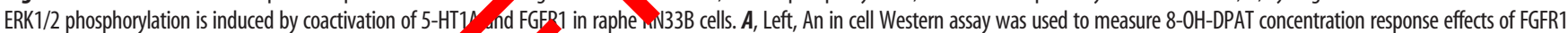
phosphorylation in RN33B cells coexpressing 5-HT1A and Fo, 1 res stors. Similar experiments were performed without stimulation (vehicle) and in the presence of the selective 5-HT1A antagonist S-WAY $10013(1 \mu \mathrm{m})$. The data represent the mean \pm SEM: ${ }^{2}$ in qu. ruplica o. Statistical analysis was performed by one-way ANOVA followed by Tukey's Multiple Comparison post hoc test. 8-OH-DPAT 50 nm, $100 \mathrm{~nm}$, and $250 \mathrm{~nm}$ groups are significantly differ c comp ed with "cle $\left({ }^{* *} p<0.01,{ }^{* * *} p<0.001,{ }^{* * *} p<0.001\right.$, respectively); combined 8-0H-DPAT + S-WAY 10013 group is significantly different compared with 8-0H-DPAT $50 \mathrm{~nm}, 100 \mathrm{~nm}$, and $2 \times{ }_{\mathrm{nm}} \mathrm{r}<0.05,{ }^{++} p<0.001,{ }^{+++} p<0.001$, respectively). Right, The synergistic increase of FGFR1 phosphorylation is blocked by the 5-HT1A

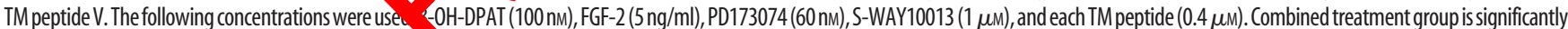
different from 8-0H-DPAT and FGF-2 alone ( ${ }^{\# \# \#} p<0.0$ and ${ }^{++} p<0.01$, respectively); the combined treatment groups with TM peptide V, 5-HT1A antagonist, and FGFR1 inhibitor, respectively, are significantly different from the combined treatment group alone $\left.{ }^{* * *} p<0.001\right)$. Statistical analysis was performed by one-way ANOVA followed by Tukey's Multiple Comparison posthoctest. $\boldsymbol{B}$, The synergistic increase of the ERK1/2 phosphorylation is blocked by the 5-HT1A TM peptide V, the siRNA ${ }^{\text {fgrr }}$ and siRNA ${ }^{\text {5ht1a }}$, but not by TM-II and the nonsilencing siRNA Alexa Fluor 488 (siRNAcont). The following concentrations were used: 8-OH-DPAT (100 nM), FGF-2 (5 ng/ml), PD173074 (60 nM), S-WAY10013 (1 $\mu \mathrm{m})$, and each TM peptide (0.4 $\mu \mathrm{m})$. Combined treatment group is significantly different from the 8-OH-DPAT and FGF-2 alone groups ( ${ }^{++}+p<0.001$ ); the combined treatment groups with TM peptide V, 5 -HT1A antagonist, and FGFR1 inhibitor are significantly different from the combined treatment group alone $\left({ }^{* * *} p<0.001\right)$; as well, the siRNA $A^{\text {ffrr }}$ and siRNA ${ }^{5 h t 1 a}$ groups markedly block the synergistic effect of the combined treatment group $\left({ }^{* * *} p<0.001\right)$. Data are mean \pm SEM, $n=5$. $C$, Time course of ERK1/2 phosphorylation was significantly different in the range of 5-120 min between the combined treatment group and FGF-2 alone and 8-0H-DPAT alone (based on the area values under the curve, ${ }^{* * *} p<0.001$ ) by one-way ANOVA followed by Tukey's Multiple Comparison post hoc test. With this analysis a significant difference between FGF-2 alone and $8-0 \mathrm{H}-\mathrm{DPAT}$ alone was observed at $10-15$ min $\left({ }^{*} p<0.05\right)$. Data are means \pm SEM $, n=6 . D, 5$-HT1A agonist markedly enhanced FGF-2-mediated RN33B cell differentiation (neurite density). Undifferentiated RN33B cells were treated without (vehicle) or with FGF-2 (50 ng/ml) and/or 8-0H-DPAT (100 nM), in the presence of TM-Il and TM-V $(0.4 \mu \mathrm{M})$ as indicated. Each $24 \mathrm{~h}$, the medium was replaced and fresh ligands were added. After a total incubation time of $3 \mathrm{~d}$, the cells were fixed and photographed. Extensions were analyzed under light microscopy. Average number of extensions per 1000 cells and mean length per 100 cells are given. Scale bar, $25 \mu \mathrm{m}$ for all panels. $\boldsymbol{d} 1$, The quantification is seen; data are presented as mean $\pm \mathrm{SEM}(n=4)$. The combined group is significantly different from $8-0 \mathrm{H}-\mathrm{DPAT}$ and FGF-2 alone $\left(^{+++} p<0.001\right)$; the group treated with TM peptide $\mathrm{V}(0.4 \mu \mathrm{m})$ is highly significantly reduced versus the combined treated group $\left({ }^{* *} p<0.01\right)$; FGF-2 is significantly different from 8-0H-DPAT alone $\left({ }^{\#} p<0.05\right)$. d2, Extension lengths/100 cells are presented for the various treatment groups as a scatter plot. The quantification includes the calculation of mean \pm SEM,$n=3$. The combined group is significantly different from $8-0 \mathrm{H}-\mathrm{DPAT}$ and FGF-2 alone ${ }^{* * *} p<0.001$ ); combined group as well as treated TM peptide Il group is highly significantly increased versus the control and treated with TM peptide V group ( ${ }^{+++} p<0.001$ ). Statistical analysis was performed by one-way ANOVA followed by Tukey's Multiple Comparison post hoc test. The $P$ value 0.05 and lower was considered significant. $\boldsymbol{E}$, Effects of TM peptide incubation on 5 -HT immunoreactivity in RN33B cell cultures after coactivation with 8-0H-DPAT and FGF-2, which produces a marked rise of 5-HT immunoreactivity [5-HT immunoreactivity (red color) was used as a marker for 5-HT synthesis and storage and NeuN immunoreactivity (green color) as a marker for neuronal nuclei]. RN33B brain-derived immortalized cells were treated for $48 \mathrm{~h}$ without (Control) or with FGF-2 (50 ng/ml) and 8-0H-DPAT (100 nM). Treatment with TM peptides $(0.4 \mu \mathrm{m})$ involved TM-II and TM-V as indicated. 5 -HT immunoreactivity was determined after immunofluorescent labeling with 5-HT/NeuN by measuring field area of 5 -HT immunoreactivity in sample fields of a constant size divided by the number of NeuN nuclei. Representative images of 5 -HT/NeuN-stained RN33B cells under different conditions are presented. Scale bar, $20 \mu \mathrm{m}$. The quantification is seen in $\boldsymbol{e} 1$, where the data are presented as mean $\pm \mathrm{SEM}, n=4$. The combined group is significantly different from 8-OH-DPAT and FGF-2 alone groups ( ${ }^{+++} p<0.001$ ); the mean 5 -HT immunoreactivity value of the group treated with TM peptide V is highly significantly reduced versus the combined treated group $\left({ }^{* *} p<0.001\right)$. Also the FGF-2-treated alone group is significantly different from the 8-0H-DPAT alone group ( ${ }^{\# \#} p<0.01$ ). The following concentrations were used: 8-OH-DPAT, $100 \mathrm{~nm}$; FGF-2, $50 \mathrm{ng} / \mathrm{ml}$; and each TM peptide, $0.4 \mu \mathrm{m}$. Statistical analysis was performed by one-way ANOVA followed by Tukey's Multiple Comparison post hoc test. The $P$ value 0.05 and lower was considered significant. 


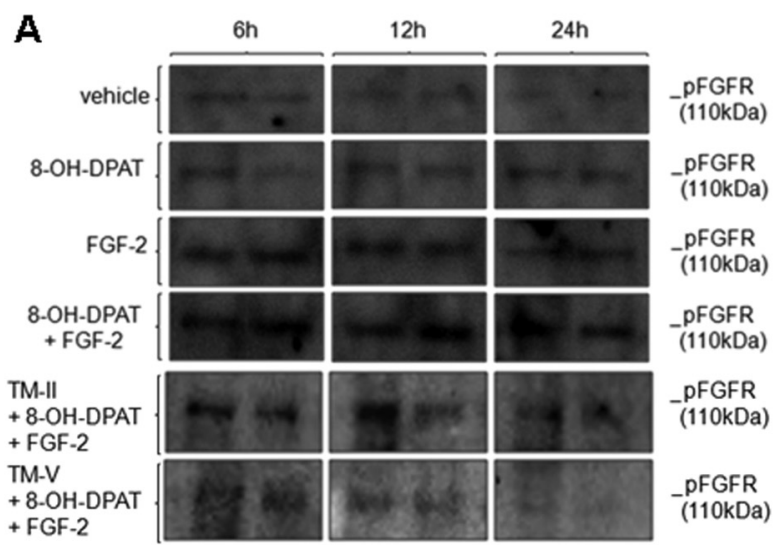

a1



Time (h)

$\rightarrow$ BanOPAT

- 8.OHOPat + FG

-a. $\mathrm{TMI}+8 . \mathrm{OH}$. DPAT +

$\rightarrow$ M $M V \cdot$ 8.OHOPAT $F$ F
B

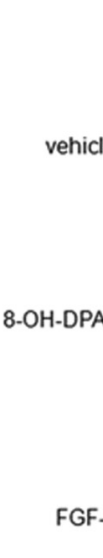

b1
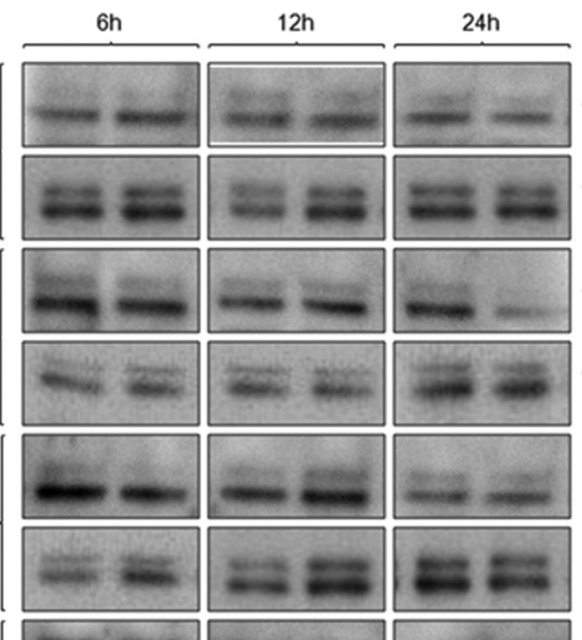

$(42 / 44 \mathrm{kDa})$

$-\underset{(42 / 44 \mathrm{kDa})}{\mathrm{pERK} 1 / 2}$
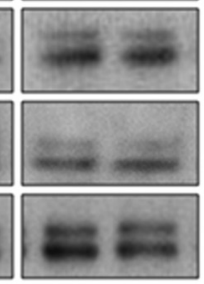

- ERK1/2

(42/44 kDa)

_pERK1/2

(42/44 kDa)
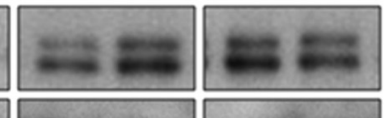

ERK1/2

-(42/44 kDa)

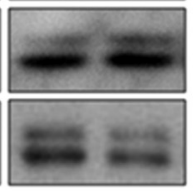

_pERK1/2

(42/44 kDa)

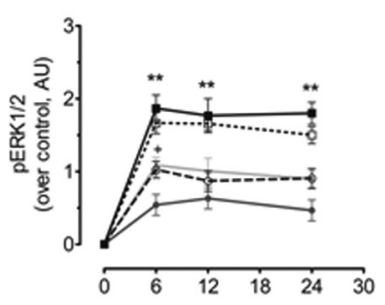

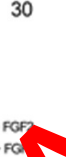

+ FGF-2

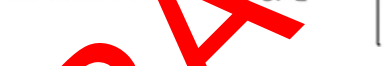

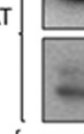

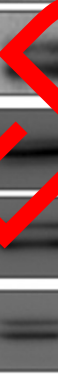

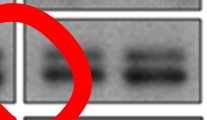

$-\frac{\mathrm{ERK} 1 / 2}{(42 / 44 \mathrm{kDa})}$
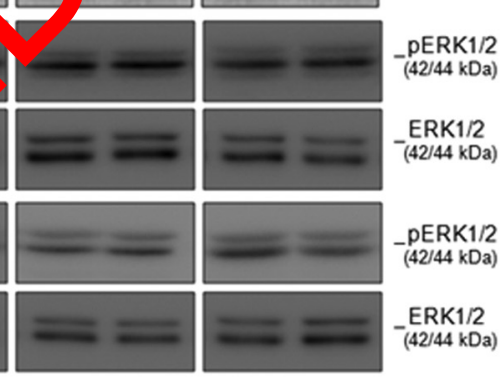

-PERK1/2

$(42 / 44 \mathrm{kDa})$

-ERK1/2

- $(42 / 44 \mathrm{kDa})$

Figure 3. $A, B$, FGFR1 transactivation and ERK1/2 phosphorylation after tracereb sventric ar treatment with FGF-2 and 8-OH-DPAT in the caudal midline area of the midbrain. Synergistic activation of ERK1/2 phosphorylation and FGFR1 phosphorylation was ob rvee caudarmidline area of the rat midbrain containing the dorsal and median raphe nuclei after intracerebroventricular coinjection of FGF-2 $(50 \mathrm{ng})$ and/or 8-OH-DPAT ( $200 \mathrm{nmol})$. D - are mean SEM. Three rats per group (total of 12 groups). The blots depicted are from two different animals (out of a total of three rats per group). Combined treated group (8-OH-DPAT + .GF-2) nd the TM reptide II-treated group (TM-II, $0.4 \mu \mathrm{M}+8-\mathrm{OH}-\mathrm{DPAT}+\mathrm{FGF}-2)$ are significantly different from FGF-2 and 8-OH-DPAT alone group and the TM peptide V-treated group ${ }^{2} \mathrm{~N}-\mathrm{V}, 0.4 \mu \mathrm{M}-\mathrm{O}-\mathrm{OH}-\mathrm{DPAT}+\mathrm{FGF}-2$ ) at the time points studied (FGFR1 transactivation, ${ }^{*} p<0.05$; ERK1/2 phosphorylation, ${ }^{* *} p<$ 0.01 ); activation of ERK1/2 at $6 \mathrm{~h}$ in the FGF-2 alone grour ad the ${ }^{\top} \mathrm{M}$ peptide V-treated group was significantly different from that in the 8-0H-DPAT alone group ( $\left.{ }^{+} p<0.05\right)$. Statistical analysis was performed by two-way ANOVA followed by Bonferron hoc tec ${ }^{*}$ The $P$ value 0.05 and lower was considered significant.

absence of the PLA cluster in EK2 with FGFR1 and 5-HT1A. Thes esults are supported by the findings of coimmunoprecipitation FFGFR1 and 5-HT1A in the caudal midline region of the midbrain, containing the dorsalis and median raphe nuclei. Also a colocation of the FGFR1 and 5-HT1A immunoreactivities was demonstrated in the majority of the 5-HT nerve cells within the dorsal and median raphe.

With the FRET technique the FGFR1-5-HT1A receptor heterocomplexes were also demonstrated in HEK293T cells transiently cotransfected with FGFR1-GFP2 and 5-HT1A-YFP. The FRET results also indicated that combined treatment with FGF-2 and 8-OH-DPAT may recruit an increased number of FGFR1-5HT1A receptor heterocomplexes in view of the increased $B_{\max }$ values observed with this combined treatment. In line with this interpretation the number of PLA-positive clusters per nerve cell markedly increased upon this cotreatment. This increase was blocked by incubation with TM-V peptide but not TM-II peptide of the 5-HT1A receptor, indicating that TM-V is part of the receptor interface.

These results together opened up the possibility that the 5-HT1A autoreceptors may in addition participate in the neurotrophism of the central 5-HT nerve cells via the formation of FGFR1-5-HT1A receptor heterocomplexes which may be dynamically regulated by combined agonist treatment.
It could in fact be demonstrated in the stable cell lines of the medullary raphe neurons that FGF-2 and 5-HT1A agonist cotreatment produced a marked enhancement of the number of processes formed by each medullary raphe cell and of the amounts of 5-HT immunoreactivity per cell. These plastic changes were specific since they were blocked by FGFR1 inhibitors and 5-HT1A antagonists and by siRNAs for FGFR1 and for 5-HT1A. The dependency of the receptor heterocomplex was indicated by the ability of the TM-V but not TM-II peptide to block these plasticity events. Thus, the results indicate that the FGFR1-5-HT1A receptor heterocomplexes may increase the plasticity of the medullary raphe 5-HT nerve cells. In agreement, this cotreatment using the same cell model led to a marked synergistic increase in the FGFR1 and ERK1/2 phosphorylation levels vs single treatment with the agonists. Like the structural plasticity events these signaling events were specific since they were blocked by FGFR1 inhibitors and 5-HT1A antagonists and by siRNAs for FGFR1 and for 5-HT1A. The dependency of the receptor heterocomplex was again indicated by the ability of the TM-V but not TM-II peptide of the 5-HT1A receptor to block these plasticity events. This increase in ERK signaling, likely involved in mediating the increase in structural plasticity observed, may be produced by the observed 5-HT1A agonist-induced transactivation of the FGFR1 as seen from its increased phos- 
phorylation levels. The molecular mechanism may involve an enhancing allosteric receptor-receptor interaction in the receptor heterocomplex (Fuxe et al., 2007).

The studies using intracerebroventricular injections of FGF-2 and/or the 5-HT1A agonist 8-OH-DPAT in rats gave in vivo evidence that the cotreatment with these agonists can synergistically increase ERK1/2 and FGFR1 phosphorylation levels in the caudal midline region containing the dorsal and median raphe nuclei rich in 5-HT nerve cell bodies (Dahlstroem and Fuxe, 1964). Thus, both in vitro and in vivo findings support the view that the signaling of the FGFR1-5-HT1A receptor heterocomplexes in the dorsal and median raphe 5-HT nerve cells may have a role in enhancing neuroplasticity in these neurons. It is of substantial interest that intracerebroventricular $\mathrm{TM}-\mathrm{V}$ of the 5-HT1A receptor, which belongs to the receptor interface, can markedly counteract the synergistic increase in FGFR1 and ERK1/2 phosphorylation after combined intracerebroventricular treatment with FGF-2 and 8-OH-DPAT. These results in fact give evidence that the FGFR1-5-HT1A receptor heterocomplexes are involved in mediating these actions in the brain. This strongly supported by the observation that intracerebroventricular TMII, which does not belong to the receptor interface, in the same dose failed to counteract these effects.

It should be noticed that BDNF, known to have antidepressantlike effects (Siuciak et al., 1997), in primary raphe cultures produces increases in neuritic lengths of 5-HT nerve cells via TrkB receptors, which are higher in the absence of 5-HT1A receptors (Rumajogee et al., 2004). These results indicate that there exist in embryonic development indirect or direct TrkB-5-HT1A receptor interactions in 5-HT nerve cells which are antagonistic in nature. Should TrkBHT1A receptor heterocomplexes exist in the raphe 5-HT nerro cells the receptor-receptor interactions within them are ther fore kely antagonistic in contrast to the synergistic receptor-rece or on tions found in the current study in the discovered GFRI- HT1A receptor heterocomplexes in the midbrain raph $-\mathrm{H}$. nerve a ds. In addition, the enhancement of the neuritic len of ths of $-\mathrm{h}$ nerve cells observed in the 5-HT1A-null mutant p.ce my be possible also through a compensatory mechanism in 1 ng th formation of FGFR1-5-HT1B receptor heteroc

Together, the results show at th $L_{\text {HT }}$ M autoreceptors by being part of a FGFR1-5-HT1A eptor heterocomplex in the midbrain raphe 5-HT nerve cells app rs to have a functional role in the central 5-HT neuron systems in addition to playing a key role in reducing the activity of these neurons as an autoreceptor (Albert et al., 1996; Artigas et al., 1996). Thus, by transactivation of FGFR1 in this receptor heterocomplex and increasing its ERK1/2 signaling, it may improve the neuroplasticity of the 5-HT nerve cells, which may contribute to antidepressant-like effects. It may be speculated that certain types of depression may develop as a result of a disruption of the FGFR1-5-HT1A receptor heterocomplex reducing the neuroplasticity and trophism of the central 5-HT neurons and leading to dysregulation of the 5-HT1A autoreceptor with abnormal reductions of the firing rate in these neurons. Future work will show whether this speculation has any value in understanding mechanisms of major depression.

\section{Notes}

Supplemental material for this article is available at http://www.neuro. ki.se/fuxe/borroto_escuela.html. Control experiments are presented demonstrating disruptive actions by distinct transmembrane peptides of the 5-HT1A-FGFR1 heterocomplex and the synergistic increase in ERK1/2 phosphorylation after coactivation with 8-OH-DPAT and FGF-2 in differentiated cells. The specificity of the siRNA-5htla and
siRNA-fgfr1 is demonstrated in CRE and SRE-luciferase reporter gene assays including a pharmacological analysis. Coimmunoprecipitation of FGFR1 and 5-HT1A is shown in the midbrain raphe tissue containing nucleus raphe dorsalis and medianus. This material has not been peer reviewed.

\section{References}

Albert PR, Le François B, Millar AM (2011) Transcriptional dysregulation of 5-HT1A autoreceptors in mental illness. Mol Brain 4:21.

Albert PR, Lembo P, Storring JM, Charest A, Saucier C (1996) The 5-HT1A receptor: signaling, desensitization, and gene transcription. Neuropsychopharmacology 14:19-25.

Artigas F, Romero L, de Montigny C, Blier P (1996) Acceleration of the effect of selected antidepressant drugs in major depression by 5-HT1A antagonists. Trends Neurosci 19:378-383.

Belluardo N, Wu G, Mudo G, Hansson AC, Pettersson R, Fuxe K (1997) Comparative localization of fibroblast growth factor receptor-1, -2 , and -3 mRNAs in the rat brain: in situ hybridization analysis. J Comp Neurol 379:226-246.

Bennasroune A, Fickova M, Gardin A, Dirrig-Grosch S, Aunis D, Crémel G, Hubert P (2004) Tran rane peptides as inhibitors of ErbB receptor signaling. Mol Bi Cell 15: 64-3474.

Bennasroune A, Gardin Auzan Clauser E, Dirrig-Grosch S, Meira M, Appert-Collin , Aunis Cr nel G, Hubert P (2005) Inhibition by transmemb ne per des ol Mimeric insulin receptors. Cell Mol Life Sci 62:2124

Berghuis Dobsza $\mathrm{MB}$ ang X, Spano S, Ledda F, Sousa KM, Schulte G, Err ors Mackie KN Paratcha G, Hurd YL, Harkany T (2005) Endocanmabinoids ulate interneuron migration and morphogenesis by transactivating the $\mathrm{rkB}$ receptor. Proc Natl Acad Sci U S A 102:19115-19120. orroto-E uela DO, Narvaez M, Marcellino D, Parrado C, Narvaez JA, Tarakanov O, Agnati LF, Díaz-Cabiale Z, Fuxe K 2010 Galanin receptor-1 tes 5-hydroxtryptamine-1A signaling via heterodimerization. Biochem Biophys Res Commun 393:767-772.

Borroto-Escuela DO, Van Craenenbroeck K, Romero-Fernandez W, Guidolin D, Woods AS, Rivera A, Haegeman G, Agnati LF, Tarakanov AO, Fuxe K 2011 Dopamine D2 and D4 receptor heteromerization and its allosteric receptor-receptor interactions. Biochem Biophys Res Commun 404:928-934.

Chadi G, Tinner B, Agnati LF, Fuxe K (1993) Basic fibroblast growth factor (bFGF, FGF-2) immunoreactivity exists in the noradrenaline, adrenaline and 5-HT nerve cells of the rat brain. Neurosci Lett 160:171-176.

Czesak M, Burns AM, Lenicov FR, Albert PR (2007) Characterization of rat rostral raphe primary cultures: multiplex quantification of serotonergic markers. J Neurosci Methods 164:59-67.

Dahlstroem A, Fuxe K (1964) Evidence for the existence of monoaminecontaining neurons in the central nervous system. I. Demonstration of monoamines in the cell bodies of brain stem neurons. Acta Physiol Scand Suppl 232:231-255.

Ferguson SS (2003) Receptor tyrosine kinase transactivation: fine-tuning synaptic transmission. Trends Neurosci 26:119-122.

Follesa P, Gale K, Mocchetti I (1994) Regional and temporal pattern of expression of nerve growth factor and basic fibroblast growth factor mRNA in rat brain following electroconvulsive shock. Exp Neurol 127:37-44.

Fuxe K, Ogren SO, Agnati L, Gustafsson JA, Jonsson G (1977) On the mechanism of action of the antidepressant drugs amitriptyline and nortriptyline. Evidence for 5-hydroxytryptamine receptor blocking activity. Neurosci Lett 6:339-343.

Fuxe K, Agnati LF, Andersson K, Calza L, Benfenati F, Zini I, Battistini N, Kohler C, Ogren SO, Hökfelt T (1983) Analysis of transmitter-identified neurons by morphometry and quantitative microfluorimetry. Evaluations of the actions of psychoactive drugs, specially sulpiride. In: Special aspects of psychopharmacology (Ackenheil M, Matussek N, eds), pp 1332. Paris: Espansion Scientifique Francaise.

Fuxe K, Hedlund P, von Euler G, Lundgren K, Martire M, Ogren S, Eneroth P, Agnati L (1991) Galanin/5-HT interactions in the rat central nervous system. Relevance for depression. In: Galanin. A new multifunctional peptide in the neuroendocrine system (Hökfelt T, Bartfai T, Jacobowitz D, Ottoson D, eds), pp 221-235. London: Wenner-Gren Center International Series.

Fuxe K, Tinner B, Zoli M, Pettersson RF, Baird A, Biagini G, Chadi G, Agnati LF (1996) Computer-assisted mapping of basic fibroblast growth factor 
immunoreactive nerve cell populations in the rat brain. J Chem Neuroanat 11:13-35.

Fuxe K, Dahlström A, Höistad M, Marcellino D, Jansson A, Rivera A, DiazCabiale Z, Jacobsen K, Tinner-Staines B, Hagman B, Leo G, Staines W, Guidolin D, Kehr J, Genedani S, Belluardo N, Agnati LF (2007) From the Golgi-Cajal mapping to the transmitter-based characterization of the neuronal networks leading to two modes of brain communication: wiring and volume transmission. Brain Res Rev 55:17-54.

Gwinn RP, Kondratyev A, Gale K (2002) Time-dependent increase in basic fibroblast growth factor protein in limbic regions following electroshock seizures. Neuroscience 114:403-409.

Hoyer D, Hannon JP, Martin GR (2002) Molecular, pharmacological and functional diversity of 5-HT receptors. Pharmacol Biochem Behav 71:533-554.

Kotecha SA, Oak JN, Jackson MF, Perez Y, Orser BA, Van Tol HH, MacDonald JF (2002) A D2 class dopamine receptor transactivates a receptor tyrosine kinase to inhibit NMDA receptor transmission. Neuron 35:1111-1122.

Lee FS, Chao MV (2001) Activation of Trk neurotrophin receptors in the absence of neurotrophins. Proc Natl Acad Sci U S A 98:3555-3560.

Lee FS, Rajagopal R, Chao MV (2002) Distinctive features of Trk neurotrophin receptor transactivation by $\mathrm{G}$ protein-coupled receptors. Cytokine Growth Factor Rev 13:11-17.

Lundberg C, Englund U, Trono D, Björklund A, Wictorin K (2002) Differentiation of the RN33B cell line into forebrain projection neurons after transplantation into the neonatal rat brain. Exp Neurol 175:370-387.

Luttrell LM, Daaka Y, Lefkowitz RJ (1999) Regulation of tyrosine kinase cascades by G-protein-coupled receptors. Curr Opin Cell Biol 11:177-183.

Mallei A, Shi B, Mocchetti I (2002) Antidepressant treatments induce the expression of basic fibroblast growth factor in cortical and hippocampal neurons. Mol Pharmacol 61:1017-1024.

Maragnoli ME, Fumagalli F, Gennarelli M, Racagni G, Riva MA (2004) Fluoxetine and olanzapine have synergistic effects in the modulation of fibroblast growth factor 2 expression within the rat brain. Biol Psychia 55:1095-1102.

Ogren SO, Fuxe K, Agnati LF, Gustafsson JA, Jonsson G, Holm Af (1979)
Reevaluation of the indoleamine hypothesis of depression. Evidence for a reduction of functional activity of central 5 -HT systems by antidepressant drugs. J Neural Transm 46:85-103.

Paxinos G, Watson C (1986) The rat brain in stereotaxic coordinates, Ed 2. Sidney: Academy.

Pazos A, Palacios JM (1985) Quantitative autoradiographic mapping of serotonin receptors in the rat brain. I. Serotonin-1 receptors. Brain Res 346:205-230.

Peroutka SJ, Snyder SH (1979) Multiple serotonin receptors: differential binding of $\left[{ }^{3} \mathrm{H}\right] 5$-hydroxytryptamine, $\left[{ }^{3} \mathrm{H}\right]$ lysergic acid diethylamide and $\left[{ }^{3} \mathrm{H}\right]$ spiroperidol. Mol Pharmacol 16:687-699.

Peroutka SJ, Snyder SH (1980) Regulation of serotonin2 (5-HT2) receptors labeled with $\left[{ }^{3} \mathrm{H}\right]$ spiroperidol by chronic treatment with the antidepressant amitriptyline. J Pharmacol Exp Ther 215:582-587.

Rajagopal R, Chen ZY, Lee FS, Chao MV (2004) Transactivation of Trk neurotrophin receptors by G-protein-coupled receptor ligands occurs on intracellular membranes. J Neurosci 24:6650-6658.

Rumajogee P, Vergé D, Hanoun N, Brisorgueil MJ, Hen R, Lesch KP, Hamon M, Miquel MC (2004) Adaption of the serotoninergic neuronal phenotype in the absence of 5-HT autoreceptors or the 5-HT transporter: involvement of BDNF and AMP. Eur J Neurosci 19:937-944.

Shah BH, Catt KJ (2004 GPCK rediated transactivation of RTKs in the CNS: mechanisms a, conseque ces. Trends Neurosci 27:48-53.

Siuciak JA, Lewis D,Wieg d SJ, ndsay RM (1997) Antidepressant-like effect of brai deriy neu ophic factor (BDNF). Pharmacol Biochem Behav 56\%

Söderberg , Gullb $\mathrm{M}$, Avius M, Ridderstråle K, Leuchowius KJ, Jarvius J, Vsto K, Hydb Ig P, Bahram F, Larsson LG, Landegren U (2006) Direct obse ation of individual endogenous protein complexes in situ by proximity ligaron. Nat Methods 3:995-1000.

rifilieff P, ives ML, Urizar E, Piskorowski RA, Vishwasrao HD, Castrillon J, Schmal SC, Slättman M, Gullberg M, Javitch JA 2011 Detection of antigen tions ex vivo by proximity ligation assay: endogenous dopamine D2adenosine A2A receptor complexes in the striatum. Biotechniques 51:111118. 